\title{
Poluição, aquecimento global e repercussöes na saúde
}

Há mais de 50 anos têm sido relatados os efeitos da poluição do ar na saúde. São bastante conhecidos os episódios decorrentes da elevação aguda na concentração de poluentes ocorridos no Vale do Meuse (Bélgica, 1930), em Donora (Pensilvânia, 1948) e em Londres, 1952, responsáveis por milhares de internações e óbitos por doenças respiratórias e cardiovasculares. Estes fatos chamaram a atenção do mundo, estimularam a realização de milhares de estudos e induziram os países a adotarem leis ambientais cada vez mais protetivas, mas ainda insuficientes.

Os estudos epidemiológicos e experimentais realizados têm comprovado, de maneira consistente, que a poluição do ar aumenta o risco de doenças e de mortalidade por doenças cardiovasculares, respiratórias e por câncer de pulmão ${ }^{1-2}$.

Nosso organismo desenvolveu, ao longo de um processo de evolução de milhões de anos, um sofisticado e eficiente mecanismo de defesa contra as doenças infecciosas e outras agressões do meio, possibilitando que chegássemos até quase meados do século passado sem o uso de antibióticos, vacinas e outros medicamentos e procedimentos. É claro, porém, que tal processo deu-se à custa de elevada mortalidade, que foi responsável pela seleção da espécie. Entretanto, não desenvolvemos mecanismos para nos defender dos efeitos gerados a partir da Revolução Industrial (gases, poeiras e radiações), processo recente (250 anos) na evolução da espécie. Nosso organismo reage a estas agressões freqüentemente de maneira parecida a como faz com relação às infecções, muitas vezes levando à lesões em vez da cura.

Ao lado dos efeitos diretos na saúde humana, cientistas têm procurado chamar a atenção para os efeitos dos poluentes no meio ambiente e da degradação ambiental, como a redução das áreas verdes provocada pela atividade humana. Mas as previsões e estudos eram considerados por muitos como catastrofistas, havendo grande resistência por parte dos países mais poluidores a enfrentar o problema apontado.

A recente divulgação do relatório do Painel Intergovernamental sobre Mudança Climática (IPCC) ${ }^{3}$, constituído em 1988 pela Organização Meteorológica Mundial (WMO) e pelo ProgramaAmbiental das Nações Unidas (UNEP), órgãos vinculados à ONU, conseguiu chamara atenção de governantes e de grande parte da população para as conseqüências danosas da ação do homem ao meio ambiente. Mesmo os Estados Unidos da América do Norte, que vêm se recusando a assinar o Protocolo de Kyoto, não puderam ficar alheios e contestar as conclusões.

Orelatório divulgado em Paris demonstrou de maneira consistente que as alterações na atmosfera com o aumento da concentração dos gases de efeito estufa (que sempre existiram e ajudam a manter a temperatura da terra estável e não muito fria, pois absorvem parte da radiação solar) e o aumento da radiação solar (decorrente da redução da camada de ozônio na estratosfera, provocada pela emissão de clorofluorcabonos (CFCs) que, sob ação da luz ultravioleta do sol, libera cloro que reage e elimina o ozônio) são responsáveis pelo ritmo do aquecimento global observado.

As previsões apontam que até o final deste século a temperatura da Terra poderá aumentar em até quatro graus, com repercussões globais como as decorrentes da elevação média do nível do mar em até $60 \mathrm{~cm}$, devido ao derretimento do gelo das calotas polares, caso os níveis de emissão de gases não sejam drasticamente reduzidos. O Relatório apresenta também dados sobre a concentração de gases de efeito estufa nos últimos dez mil anos, demonstrando que seu aumento relevante teve início a partir de 1750, com importante incremento nos últimos 50 anos. A concentração de dióxido de carbono $\left(\mathrm{CO}_{2}\right)$, o mais importante dos gases de efeito estufa gerado pela atividade do homem (outros são o metano, óxidos nitrosos, ozônio) passou de 280 ppm (partes por milhão), na era préindustrial, para 379 ppm, em 2005, com aumento exponencial nas últimas décadas. Ataxa de crescimento de $\mathrm{CO}_{2}$ nos últimos dezanos ( I 995-2005) foi de I, 9 ppm/ano, contra I,4 ppm/ano no período de 1960-2005. Elevação semelhante foi observada para os óxidos nitrosos e o metano, todos relacionados à queima de combustíveis fósseis (derivados do petróleo, carvão) e de biomassa (queimadas de cana-de-açúcar e de florestas).

Os dados comprovam também que com o aumento das concentrações dos gases de efeito estufa (assim chamados por absorverem radiação solar e aumentarem o aquecimento na superfície da Terra - a troposfera), verifica-se um correspondente e concomitante aumento da temperatura, da velocidade de derretimento das geleiras polares e da elevação do nível do mar.

Ao mesmo tempo em que este processo ocorre, a eliminação de áreas verdes e a redução de fitoplâncton nos oceanos pela ação da radiação ultravioleta que atinge a superfície da Terra em maior quantidade devido à redução da camada de ozônio, reduzem a capacidade de extração de $\mathrm{CO}_{2}$, contribuindo assim para favorecer ainda mais o aquecimento

Em síntese, a ação do homem tem levado à poluição do ar; destruído a camada de ozônio da estratosfera, que desempenha a função de reduzir a quantidade de radiação solar que atinge a superfície da Terra (troposfera); provocado o aumento das concentrações de gases de efeito estufa $\left(\mathrm{CO}_{2}, \mathrm{O}_{3}\right.$, metano, $\left.\mathrm{NOx}\right)$ na troposfera, absorvendo maior quantidade de radiação solar e retendo calor; etem reduzido a capacidade de captação de $\mathrm{CO}_{2}$ pela eliminação de áreas verdes e degradação da flora dos oceanos, levando assim às alterações climáticas como o aquecendo global, alterações pluviométricas, secas, aumentado a freqüência de catástrofes, além dos efeitos 
diretos na saúde. Estimativas ${ }^{4}$ atuais atribuem cerca de 800 mil óbitos à poluição do ar ambiental, I,6 milhão à poluição do ar no interior dos domicílios e 154 mil óbitos às alterações climáticas; são cerca de 2,5 milhões de mortes evitáveis a cada ano e que, ao se manter os níveis atuais de emissões e destruição da natureza, tendem a aumentar.

$\bigcirc$ Brasil, embora não esteja entre os principais poluidores e emissores de gases de efeito estufa, também precisa tomar medidas drásticas que contribuam para reduzir a degradação do meio ambiente. Ampliar a rede de transportes coletivos, sobretudos nas regiões metropolitanas, desestimulando as emissões veiculares, eliminar as injustificadas queimadas de cana-de-açúcar e de florestas, fruto da ganância e da busca do lucro fácil, e ampliar o já bem-sucedido esforço no desenvolvimento e uso de fontes não poluentes ou menos poluentes, como o biodiesel e álcool, são medidas possíveis de serem implantadas a curto prazo e, assim, contribuir para a preservação da saúde e da vida em nosso Planeta.

Ubiratan de Paula Santos

Referências

I. Brunekreef B, Holgate ST. Air pollution and Health. Intergovernmenta Panel on Climate Change (IPCC). Summary for Policymakers. Lancet. 2002;360(934 I): | 233-42

2. Pope CA 3rd, Burnett RT, Thun MI, Calle EE, Krewski D, Ito K, et al. Lung cancer, cardiopulmonary mortality, and long-term exposure to fine particulate air pollution. JAMA. 2002;287(9): ||32-4|.

3. Contribution of Working Group I to the Fourth Assessment Report of the Intergovernmental Panel on Climate Change. Paris; 2007

4. Ezzati M, Lopez AD, Rodgers A, Vander Hoorn S, Murray CJ Comparative Risk Assessment Collaborating Group. Selected major risk factors and global and regional burden of disease. Lancet. 2002;360(9343): 1347-60. 